\title{
Versatile On-Resin Synthesis of High Mannose Glycosylated Asparagine with Functional Handles
}

\author{
Rui Chen ${ }^{\mathrm{a}, 1}$, Mark A. Pawlicki ${ }^{\mathrm{b}, 2}$, and Thomas J. Tolbertc, ${ }^{\mathrm{*}}$ \\ aDepartment of Chemistry, Indiana University, Bloomington, Indiana 47405 \\ bInterdisciplinary Biochemistry Graduate Program, Indiana University, Bloomington, Indiana \\ 47405 \\ 'Department of Pharmaceutical Chemistry, The University of Kansas, Lawrence, KS 66047
}

\section{Abstract}

Here we present a synthetic route for solid phase synthesis of $\mathrm{N}$-linked glycoconjugates containing high mannose oligosaccharides which allows the incorporation of useful functional handles on the $\mathrm{N}$-terminus of asparagine. In this strategy, the $\mathrm{C}$-terminus of an Fmoc protected aspartic acid residue is first attached to a solid phase support. The side chain of aspartic acid is protected by a 2phenylisopropyl protecting group, which allows selective deprotection for the introduction of glycosylation. By using a convergent on-resin glycosylamine coupling strategy, an N-glycosidic linkage is successfully formed on the free side chain of the resin bound aspartic acid with a large high mannose oligosaccharide, $\mathrm{Man}_{8} \mathrm{GlcNAc}_{2}$, to yield N-linked high mannose glycosylated asparagine. The use of on-resin glycosylamine coupling provides excellent glycosylation yield, can be applied to couple other types of oligosaccharides, and also makes it possible to recover excess oligosaccharides conveniently after the on-resin coupling reaction. Useful functional handles including an alkene (p-vinylbenzoic acid), an alkyne (4-pentynoic acid), biotin, and 5carboxyfluorescein are then conjugated onto the $\mathrm{N}$-terminal amine of asparagine on-resin after the removal of the Fmoc protecting group. In this way, useful functional handles are introduced onto the glycosylated asparagine while maintaining the structural integrity of the reducing end of the oligosaccharide. The asparagine side chain also serves as a linker between the glycan and the functional group and preserves the native presentation of $\mathrm{N}$-linked glycan which may aid in biochemical and structural studies. As an example of a biochemical study using functionalized high mannose glycosylated asparagine, a fluorescence polarization assay has been utilized to study the binding of the lectin Concanavalin A (ConA) using 5-carboxyfluorescein labeled high mannose glycosylated asparagine.

(C) 2013 Elsevier Ltd. All rights reserved.

*To whom correspondence should be addressed. Thomas J. Tolbert, Department of Pharmaceutical Chemistry, The University of Kansas, 2095 Constant Avenue, Lawrence, KS 66047, tolbert@ku.edu. Tel: (785) 864-1898. Fax: (785) 864-5736.

1 Present address GenScript USA Inc., 860 Centennial Ave., Piscataway, NJ 08801.

2 Present address Sigma-Aldrich, 3500 Dekalb St., St. Louis, MO 63118.

Supporting Information

Experimental procedures, ${ }^{1} \mathrm{H}$ NMR spectra and accurate MS spectra of synthesized compounds $\mathbf{1 , 2}, \mathbf{3 , 4}$, and $\mathbf{5}$

Publisher's Disclaimer: This is a PDF file of an unedited manuscript that has been accepted for publication. As a service to our customers we are providing this early version of the manuscript. The manuscript will undergo copyediting, typesetting, and review of the resulting proof before it is published in its final citable form. Please note that during the production process errors may be discovered which could affect the content, and all legal disclaimers that apply to the journal pertain. 


\section{Keywords}

Solid Phase Synthesis; Glycosylated Asparagine; High Mannose; Glycosylamine; On-resin Coupling; Functionalized Oligosaccharide

\section{Introduction}

$\mathrm{N}$-linked glycosylation is a ubiquitous posttranslational modification which plays important roles $^{1-3}$ in protein folding and stability, cellular recognition, immune responses, and the development of protein therapeutics. ${ }^{4-6}$ In order to fulfill these complex functions nature endows $\mathrm{N}$-linked glycans with enormous structural diversity, thereby creating significant challenges in the study of their structure and function. In addition to these challenges, $\mathrm{N}$ linked glycans, like most carbohydrates, lack good chromophores that can be used as biophysical probes, and are often involved in weak multivalent interactions making it desirable to study carbohydrate multimers instead of monomers. Functionalization of Nlinked glycans can be used to introduce labels and reactive handles to overcome these problems and facilitate biochemical studies. ${ }^{7-16}$ Common methods used to conjugate labels to the free reducing end of carbohydrates, such as reductive amination, destroy the reducing end monosaccharide, and this is often undesirable. ${ }^{10,17-19}$ Because of this, new methods to produce functionalized $\mathrm{N}$-linked glycoconjugates are valuable.

Here we present an application of our recently reported on-resin convergent synthesis of $\mathrm{N}$ linked glycopeptides to the production of functionalized glycosylated asparagine. ${ }^{20} \mathrm{We}$ utilize a free reducing end high mannose oligosaccharide derived from yeast to demonstrate this method, but the strategy presented here can be applied to a variety of $\mathrm{N}$-linked glycans obtained from PNGase F digestion of glycoproteins from different sources. This method takes advantage of solid phase chemistry to create a common glycosylated precursor that can be converted into a wide range of functionalized glycans. By coupling the $\mathrm{N}$-linked glycan to asparagine, the reducing end $\mathrm{N}$-acetylglucosamine (GlcNAc) remains intact and is presented in a natural $\mathrm{N}$-glycosidic linkage. Additionally, the asparagine side chain serves as a linker spacing the glycan from the functional handle that is attached to the asparagine $\mathrm{N}$ terminus. In this strategy (as described in Figure 1a), the C-terminus of an Fmoc amine protected aspartic acid residue is first attached to a solid phase support. The side chain of aspartic acid is selectively protected by a 2-phenylisopropyl protecting group, which allows selective on-resin deprotection of the side chain for the introduction of glycosylation. By using convergent on-resin glycosylamine coupling, an $\mathrm{N}$-glycosidic linkage is successfully formed on the free side chain of the resin bound aspartic acid. Next, useful functional handles can be incorporated onto the N-terminal amine after the removal of the Fmoc protecting group. Subsequent resin cleavage provides the desired $\mathrm{N}$-linked glycosylated asparagine with functional handles incorporated at $\mathrm{N}$-terminus. This strategy is demonstrated by the solid phase synthesis of N-linked glycosylated asparagines containing a large high mannose oligosaccharide, $\mathrm{Man}_{8} \mathrm{GlcNAc}_{2}$ (Figure 1b), and the incorporation of various functional handles at the $\mathrm{N}$-terminus including an alkene (p-vinylbenzoic acid), an alkyne (4-pentynoic acid), biotin, and 5-carboxyfluorescein (Figure 1c).

\section{Experimental}

\subsection{Materials and Equipment}

3-(Diethoxyphosphoryloxy)-1, 2, 3-benzotriazin-4(3H)-one (DEPBT) was purchased from AAPPTEC. Methyl sulfoxide (DMSO, 99.9\%), 4-Vinylbenzoic acid (97\%), 4-Pentynoic acid (95\%), biotin (99\%), N,N-Diisopropylethylamine (DIEA, 99\%), Dichloromethane (DCM, 99.5\%), Trifluoroacetic acid (TFA, 99\%), Triisopropylsilane (TIS, 99\%) and N,N- 
Dimethylformamide (DMF, 99\%) were purchased from Sigma-Aldrich. 5-

Carboxyfluorescein was purchased from AnaSpec Inc. Rink Amide PEGA resin (50-100 mesh, $0.20-0.50 \mathrm{mmol} / \mathrm{g})$ and, the Fmoc-Asp $(\mathrm{O}-2 \mathrm{PhiPr})-\mathrm{OH}$ building block were purchased from EMD Biosciences. The $\mathrm{Man}_{8} \mathrm{GlcNAc}_{2}$ used in this study was obtained from extraction from yeast (manuscript in preparation). Pierce Economy Mini-Spin Columns $(0.8 \mathrm{~mL}$ resin capacity) from Thermo Scientific were used for on-resin coupling of glycosylamines. Preparative RP-HPLC was conducted using a Hyper prep 120 C18 column (length $250 \mathrm{~mm}$, I.D. $10 \mathrm{~mm}$ ), and NP-HPLC was conducted using an Apex Silica column (length $250 \mathrm{~mm}$, I.D. $4.6 \mathrm{~mm}$ ). Isolated yields refer to chromatographically pure compounds. Theoretical yields were calculated based on the amino acid loadings of the resins, which were determined by quantification of Fmoc removal by UV at $301 \mathrm{~nm}\left(\varepsilon=7800 \mathrm{~cm}^{-1} \mathrm{M}^{-1}\right) .{ }^{21} 400$ and $500 \mathrm{MHz}{ }^{1} \mathrm{H}-\mathrm{NMR}$ was carried on a Varian Inova NMR Spectrometer. Masses were determined either by a Bruker Autoflex III MALDI-TOF or a Waters/Micromass LCT Mass spectrometer. Fluorescence spectra were recorded on a Photon Technology International QM-4-CW spectrofluorometer with FeliX32 software. Isothermal Titration Calorimetry was performed using a VP-ITC calorimeter from Microcal, Inc.

\subsection{Preparation of glycosylamine $(1)^{20,22}$}

10 to $100 \mathrm{mg}$ of free reducing end $\mathrm{Man}_{8} \mathrm{GlcNAc}_{2}$ were dissolved in 10 to $25 \mathrm{~mL}$ of saturated $\mathrm{NH}_{4} \mathrm{HCO}_{3}$ in water and stirred for 5-6 days at room temperature. Repetitive rotary evaporation and lyophilization were utilized to remove the residual ammonium hydrogen carbonate. ${ }^{1} \mathrm{H}-\mathrm{NMR}$ was employed to confirm the conversion of free sugars into the corresponding $\beta$-D-glycosylamine.

\subsection{On-resin coupling of glycosylamine (1) to aspartic acid 20}

Manual loading of protected aspartic acid onto Rink Amide PEGA resin $(0.01 \mathrm{mmol})$ was carried out by using 5 equivalents of Fmoc-Asp(O-2PhiPr)-OH, 5 equivalents of DEPBT, and 3 equivalents of DIEA. The loading was determined by quantification of Fmoc removal by UV at $301 \mathrm{~nm}\left(\varepsilon=7800 \mathrm{~cm}^{-1} \mathrm{M}^{-1}\right)$ for a resin sample. ${ }^{21}$ Capping was performed to inactivate any un-reacted amino groups by using a large excess of acetic anhydride with 3 equivalents of N-methylmorpholine in DCM. Before the on-resin glycosylation reaction, the PhiPr protecting group was selectively removed by the treatment with 94:1:5 DCM/TFA/ TIS for 2 min, repeated 4 times. DCM, DMF and then DMSO were used to wash the resin thoroughly, which was then transferred into the reaction column pre-swelled with DMSO. 3 equivalents of glycosylamine 1, 3 equivalents of the coupling reagent DEPBT and 1.5 equivalents of the base DIEA in DMSO were added. The reaction column was sealed carefully and attached to a rotator which was rotated at $30 \mathrm{rpm}$. The on-resin glycosylation reaction was repeated twice (double coupling), with 6 hours for each coupling for a total 12 hour reaction time. Before the second coupling, the reaction solution was drained off by filtration and the resin was washed 3 times by DMSO, then fresh reagents were added for the second coupling. The reaction solutions were collected by filtration and stored at $-20{ }^{\circ} \mathrm{C}$ for later glycan recovery.

\subsection{Analytical HPLC for determination of glycosylation yields}

Crude samples cleaved from small quantities of resin obtained from 2.3 as described above were cleaved by treatment with neat TFA containing $1 \%$ TIS scavenger for 3 hours and analyzed by analytical HPLC ( $0-80 \%$ B in 10 min using a Beckman SGB with a $0.46 \times 5$ cm Zorbax C8 column, A buffer: Water, 0.1\% TFA, B buffer: $90 \%$ Acetonitrile, $10 \%$ Water, $0.1 \% \mathrm{TFA}$, detection at $254 \mathrm{~nm}$ ). Individual peaks were assigned by mass spectrometry and their absorption signals were integrated using Peaksimple 2000 version 2.83 (SRI 
Instruments). The glycosylation yields referred to the percentage distribution of glycosylated asparagine in the crude samples.

\subsection{On-resin N-terminal labeling}

The Fmoc group on the N-terminus was removed by treatment with piperidine (20\%) in DMF, for $10 \mathrm{~min}$ repeated 3 times. The resulting resin was washed thoroughly by DCM and DMF before on-resin $\mathrm{N}$-terminus labeling. 10 equivalents of each of the labeling compounds respectively (4-Vinylbenzoic acid, 4-Pentynoic acid, biotin and 5-Carboxyfluorescein), 10 equivalents of DEPBT and 3 equivalents of DIEA were added into the reaction column, which was then attached to a rotator $(30 \mathrm{rpm})$. The reaction time was typically 6 hours. Ninhydrin tests were employed to determine the completion of reactions. ${ }^{23}$

\subsection{Resin cleavage and purification to produce glycosylated asparagines (2-5)}

Products were cleaved off resin by treatment with neat TFA containing $1 \%$ TIS scavenger. Crude samples were precipitated and washed by diethyl ether and then purified by RPHPLC (Hyper prep $120 \mathrm{C} 18$ 8u, Length $250 \mathrm{~mm}$, I.D. $10 \mathrm{~mm}$ ). Fractions containing products were identified by mass spectrometry, pooled and lyophilized. The RP-HPLC purified samples were then further cleaned by NP-HPLC HPLC system (Apex Silica 5u, length $250 \mathrm{~mm}$, I.D. $4.6 \mathrm{~mm}$ ) to yield final pure products. ${ }^{1} \mathrm{H}-\mathrm{NMR}$ and mass spectrometry were employed for characterization. Theoretical yields were calculated based on the amino acid loadings of the resins, which were determined by quantification of Fmoc removal by $\mathrm{UV}$ at $301 \mathrm{~nm}\left(\varepsilon=7800 \mathrm{~cm}^{-1} \mathrm{M}^{-1}\right){ }^{21}$

\subsection{Characterization}

VBA-Asn ( Man $_{\mathbf{8}} \mathrm{GICNAC}_{2}$ )-CONH $\mathbf{2}_{\mathbf{2}} \mathbf{2}^{1} \mathrm{H}$ NMR (500 MHz, DEUTERIUM OXIDE) $\delta$ ppm 7.803 (d, $J=8.3 \mathrm{~Hz}, 2 \mathrm{H}) 7.645(\mathrm{~d}, J=8.3 \mathrm{~Hz}, 2 \mathrm{H}) 6.873(\mathrm{dd}, J=17.8,11.0 \mathrm{~Hz}, 1 \mathrm{H})$ $5.998(\mathrm{~d}, J=18.1 \mathrm{~Hz}, 1 \mathrm{H}) 5.467(\mathrm{~d}, J=11.2 \mathrm{~Hz}, 1 \mathrm{H}) 5.361(\mathrm{~s}, 1 \mathrm{H}) 5.328(\mathrm{~s}, 1 \mathrm{H}) 5.170(\mathrm{~s}, 1$ H) $5.108(\mathrm{~s}, 1 \mathrm{H}) 5.091-5.065(\mathrm{~m}, 3 \mathrm{H}) 4.999(\mathrm{dd}, J=8.8,4.9 \mathrm{~Hz}, 1 \mathrm{H}) 4.890(\mathrm{~s}, 1 \mathrm{H}) 4.613$ (br., $1 \mathrm{H}) 4.253(\mathrm{~s}, 1 \mathrm{H}) 4.167$ (s, $1 \mathrm{H}) 4.066-4.145(\mathrm{~m}, 5 \mathrm{H}) 2.966-3.055(\mathrm{~m}, 1 \mathrm{H}) 2.837$ $-2.926(\mathrm{~m}, 1 \mathrm{H}) 2.076(\mathrm{~s}, 3 \mathrm{H}) 1.735$ (s, $3 \mathrm{H})$. HRESI-TOF MS of VBA-Asn $\left(\mathrm{Man}_{8} \mathrm{GlcNAc}_{2}\right)-\mathrm{CONH}_{2} 2$, expected mass for $[\mathrm{M}+2 \mathrm{Na}]^{2+}=1004.8361$, observed: 1004.8399. Isolated yield $85 \%$.

Biotin-Asn ( Man $_{\mathbf{8}} \mathrm{GICNAC}_{\mathbf{2}}$ )-CONH $\mathbf{C O}_{\mathbf{3}}$ - ${ }^{1} \mathrm{H}$ NMR (500 MHz, DEUTERIUM OXIDE) $\delta$ ppm $5.363(\mathrm{~s}, 1 \mathrm{H}) 5.328(\mathrm{~s}, 1 \mathrm{H}) 5.170(\mathrm{~s}, 1 \mathrm{H}) 5.109(\mathrm{~s}, 1 \mathrm{H}) 5.044-5.099(\mathrm{~m}, 3 \mathrm{H}) 4.893$ $(\mathrm{s}, 1 \mathrm{H}) 4.594-4.660(\mathrm{~m}, 2 \mathrm{H}) 4.454(\mathrm{dd}, J=7.8,4.4 \mathrm{~Hz}, 1 \mathrm{H}) 4.255(\mathrm{~d}, J=2.0 \mathrm{~Hz}, 1 \mathrm{H})$ $4.169(\mathrm{~s}, 1 \mathrm{H}) 4.127-4.092(\mathrm{~m}, 5 \mathrm{H}) 3.018-3.064(\mathrm{~m}, 2 \mathrm{H}) 2.940-2.921(\mathrm{~m}, 1 \mathrm{H}) 2.871-$ $2.726(\mathrm{~m}, 2 \mathrm{H}) 2.340(\mathrm{~m}, 2 \mathrm{H}) 2.072(\mathrm{~s}, 3 \mathrm{H}) 2.034(\mathrm{~s}, 3 \mathrm{H}) 1.535-1.774(\mathrm{~m}, 4 \mathrm{H}) 1.332$ $1.514(\mathrm{~m}, 2 \mathrm{H})$. HR MALDI-TOF-MS of Biotin-Asn ( $\left.\mathrm{Man}_{8} \mathrm{GlcNAc}_{2}\right)-\mathrm{CONH}_{2} \mathbf{3}$, expected mass for $[\mathrm{M}+\mathrm{Na}]^{+}=2082.7182$, observed: 2082.7141. Isolated yield $65 \%$.

PA-Asn (Man ${ }_{\mathbf{8}} \mathrm{GICNAc}_{\mathbf{2}}$ )-CONH $\mathbf{C}_{\mathbf{2}}$ - ${ }^{1} \mathrm{H}$ NMR (500 MHz, DEUTERIUM OXIDE) $\delta$ ppm $5.362(\mathrm{~s}, 1 \mathrm{H}) 5.327(\mathrm{~s}, 1 \mathrm{H}) 5.169(\mathrm{~s}, 1 \mathrm{H}) 5.108(\mathrm{~s}, 1 \mathrm{H}) 5.041-5.087(\mathrm{~m}, 3 \mathrm{H}) 4.891$ (s, $1 \mathrm{H}) 4.613(\mathrm{~m}, 1 \mathrm{H}) 4.254(\mathrm{~s}, 1 \mathrm{H}) 4.168(\mathrm{~s}, 1 \mathrm{H}) 4.076-4.143(\mathrm{~m}, 5 \mathrm{H}) 2.871(\mathrm{~m}, 1 \mathrm{H})$ $2.762-2.865(\mathrm{~m}, 2 \mathrm{H}) 2.530(\mathrm{~s}, 4 \mathrm{H}) 2.082(\mathrm{~s}, 3 \mathrm{H}) 2.034(\mathrm{~s}, 3 \mathrm{H})$. HRMALDI-TOF-MS of PA-Asn $\left(\mathrm{Man}_{8} \mathrm{GlcNAc}_{2}\right)-\mathrm{CONH}_{2} 4$, expected mass for $[\mathrm{M}+\mathrm{Na}]^{+}=1936.6668$, observed: 1936.6644. Isolated yield $80 \%$.

5-FAM-Asn(Man ${ }_{\mathbf{8}} \mathrm{GICNAC}_{\mathbf{2}}$ )-CONH $\mathbf{2}_{\mathbf{2}}$ 5- $^{1} \mathrm{H}$ NMR (500 MHz, DEUTERIUM OXIDE) $\delta$ ppm $8.273(\mathrm{~d}, J=2.0 \mathrm{~Hz}, 1 \mathrm{H}) 8.045(\mathrm{dd}, J=7.9,1.8 \mathrm{~Hz}, 1 \mathrm{H}) 7.518(\mathrm{~d}, J=8.1 \mathrm{~Hz}, 1 \mathrm{H}) 7.217$ (dd, J=9.3, 3.7 Hz, 2 H) $6.745(\mathrm{~d}, J=1.0 \mathrm{~Hz}, 2 \mathrm{H}) 6.713(\mathrm{dd}, J=9.3,2.0 \mathrm{~Hz}, 2 \mathrm{H}) 5.359$ (s, 1 
H) 5.326 (s, 1 H) 5.167 (s, 1 H) 5.127 - 5.107 (m, 2 H) 5.065 (br., 2 H) 4.890 (s, 1 H) 4.577

- $4.634(\mathrm{~m}, 1 \mathrm{H}) 4.251$ (d, J=2.4 Hz, $1 \mathrm{H}) 4.167$ (s., $1 \mathrm{H}) 4.073$ - 4.131 (m, 5 H) 3.098 -

$3.042(\mathrm{~m}, 1 \mathrm{H}) 2.943(\mathrm{dd}, J=16.0,8.4 \mathrm{~Hz}, 1 \mathrm{H}) 2.060$ (s, $3 \mathrm{H}) 1.882$ (s, $3 \mathrm{H})$. HRMALDI-

TOF-MS of 5-FAM-Asn $\left(\mathrm{Man}_{8} \mathrm{GlcNAc}_{2}\right)-\mathrm{CONH}_{2} \mathbf{5}$, expected mass for $[\mathrm{M}+\mathrm{Na}]^{+}=$ 2214.6883, observed: 2214.6905. Isolated yield 70\%.

\subsection{Recovery of un-reacted high mannose glycan}

The excess un-reacted high mannose glycan was collected by filtration from different onresin coupling trials, pooled together and precipitated and then washed by diethyl ether anhydrous. The precipitate was then purified by silica gel flash chromatography (ethyl acetate/methanol/ water, 10:3:3 to 5:3:3) to give $\mathrm{Man}_{8} \mathrm{GlcNAc}_{2}$ with good yields. ${ }^{20}$

\subsection{Fluorescence polarization assay}

A fluorescence polarization assay was performed on a Photon Technology International QM-4-CW spectrofluorometer with FeliX32 software. Both Concanavalin A (ConA) and 5FAM-Asn( $\left.\mathrm{Man}_{8} \mathrm{GlcNAc}_{2}\right)-\mathrm{CONH}_{2} \mathbf{5}$ were prepared in the same aqueous buffer containing $0.1 \mathrm{M}$ Hepes, $0.15 \mathrm{M} \mathrm{NaCl}, 1 \mathrm{mM} \mathrm{MnCl} 2,1 \mathrm{mM} \mathrm{CaCl}_{2},, \mathrm{pH}=7.2$. The concentration of ConA was assessed by UV absorbance at $280 \mathrm{~nm}$ using the extinction coefficient $32,430 \mathrm{~cm}^{-1} \mathrm{M}^{-1}$ as calculated by the method described by Pace et al. ${ }^{24}$ The concentration of 5-FAMAsn $\left(\mathrm{Man}_{8} \mathrm{GlcNAc}_{2}\right)-\mathrm{CONH}_{2} \mathbf{5}$ solution was determined by UV absorbance at $496 \mathrm{~nm}$ using the extinction coefficient $80,000 \mathrm{~cm}^{-1} \mathrm{M}^{-1}$ in $0.1 \mathrm{~N} \mathrm{NaOH}$. The absorbance and emission wavelength of the spectrofluorometer were set as $493 \mathrm{~nm}$ and $523 \mathrm{~nm}$ respectively. The $\mathrm{G}$ factor of spectrofluorometer measurement was corrected for every reading. $3 \mathrm{~mL} 20 \mathrm{nM}$ concentration of 5-FAM-Asn( $\mathrm{Man}_{8} \mathrm{GlcNAc}_{2}$ )- $\mathrm{CONH}_{2} \mathbf{5}$ solution was gradually titrated by small, $\mu \mathrm{L}$ volumes of a $100 \mu \mathrm{M}$ solution of ConA. The sample's fluorescence anisotropy values were recorded for each titration point. Then a $500 \mu \mathrm{M}$ solution of the free sugar $\mathrm{Man}_{8} \mathrm{GlcNAc}_{2}$ in the same buffer was gradually titrated by addition of small, $\mu \mathrm{L}$ volumes into the sample, and fluorescence anisotropy values were recorded for each titration point as well. The resulting binding and binding inhibition plots are shown in Figure 4. A single-site binding curve was used to fit the data using Origin software to give a $\mathrm{K}_{\mathrm{d}}$ for ConA of 444 nM. ${ }^{14,25}$

\subsection{Isothermal titration calorimetry assay}

Isothermal Titration Calorimetry was performed using a VP-ITC calorimeter from Microcal, Inc. Both the free sugar Man ${ }_{8} \mathrm{GlcNAc}_{2}$ and ConA were suspended in the same degassed buffer $\left(0.1 \mathrm{M}\right.$ Hepes, $\left.0.9 \mathrm{M} \mathrm{NaCl}, 1 \mathrm{mM} \mathrm{MnCl}_{2}, 1 \mathrm{mM} \mathrm{CaCl}_{2}, \mathrm{pH}=7.2\right)$. The concentration of the dissolved $\mathrm{Man}_{8} \mathrm{GlcNAc}_{2}$ sample was accurately assessed by a mannose assay as described previously. ${ }^{26}$ The concentration of ConA was assessed by UV absorbance at 280 $\mathrm{nm}$ using the extinction coefficient $32,430 \mathrm{~cm}^{-1} \mathrm{M}^{-1}$ as calculated by the method described by Pace et al. ${ }^{24}$ Approximately $300 \mu \mathrm{l}$ of the $\mathrm{Man}_{8} \mathrm{GlcNAc}_{2}$ substrate was titrated into 1.4 $\mathrm{mL}$ of the ConA solution in $4 \mu \mathrm{l}$ increments. The temperature was kept at $15^{\circ} \mathrm{C}$ with stirring at $310 \mathrm{rpm}$. Titration of $\mathrm{Man}_{8} \mathrm{GlcNAc}_{2}$ into the same ConA buffer but with the absence of ConA was used as a control experiment to correct the error from dilution heat. A single-site binding curve was used to fit the data using Origin software to give a $\mathrm{K}_{\mathrm{d}}$ for $\mathrm{Man}_{8} \mathrm{GlcNAc}_{2}$ of $506 \mathrm{nM}$.

\section{Results and Discussion}

\subsection{Design and on-resin synthesis of high mannose glycosylated asparagine}

During our studies of on-resin convergent synthesis of $\mathrm{N}$-linked glycopeptides, reported in reference 6 , we discovered that coupling of the large high mannose glycosylamine 
$\mathrm{Man}_{8} \mathrm{GlcNAc}_{2} \mathrm{NH}_{2} \mathbf{1}$ to the free side chains of resin bound Fmoc-Asp and Fmoc-Glu resulted in excellent glycosylation yields. ${ }^{20}$ On-resin glycosylation yields can be influenced by several factors including resin type, coupling reagents and solvents, and peptide structure. Because of this it is not always simple to obtain high glycosylation yields on-resin. Having obtained high on-resin glycosylation yields for Fmoc-Asp and Fmoc-Glu in the course of our glycopeptide synthesis studies, we recognized that the reaction conditions we developed might also be applied to the rapid and efficient production of functionalized glycosylated asparagines for biochemical studies. To explore this possibility we undertook the on-resin synthesis of a small library of functionalized glycosylated asparagines. The solid phase support Rink amide PEGA resin was employed for this study since it has been demonstrated to allow access for chemistry involving large, hydrophilic oligosaccharides. ${ }^{20,}{ }^{27}$ The 2phenylisopropyl protecting group ${ }^{28}$, which can be selectively deprotected by treatment with $1 \%$ trifluoroacetic acid (TFA), was used to protect the side chain of aspartic acid, and allows for the selective introduction of glycosylation. Aspartic acid with N-terminal Fmoc and side chain 2-phenylisopropyl protecting groups (Fmoc-Asp $(\mathrm{O}-2-\mathrm{PhiPr}-\mathrm{OH})$ was loaded onto the resin manually. Capping was performed after amino acid loading to prevent any remaining uncoupled amine groups on-resin from complicating the rest of the synthesis. After removal of the 2-phenylisopropyl side chain protecting group of aspartic acid with $1 \%$ TFA, optimized glycosylation reaction conditions developed for solid phase $\mathrm{N}$-linked glycopeptide synthesis were utilized. ${ }^{20}$ On-resin glycosylation reaction conditions consisting of 3 equivalents of the high mannose glycosylamine $\mathrm{Man}_{8} \mathrm{GlcNAc}_{2} \mathrm{NH}_{2} \mathbf{1}, 3$ equivalents of 3-(Diethoxyphosphoryloxy)-1, 2, 3-benzotriazin-4(3H)-one (DEPBT) and 1.5 equivalents of $\mathrm{N}, \mathrm{N}$-diisopropylethylamine (DIEA) in dimethyl sulfoxide (DMSO) were applied to form the $\mathrm{N}$-glycosidic linkage. The on-resin glycosylation reaction was repeated twice (double coupling), with 6 hours for each coupling for a total 12 hour reaction time. Then, a sample of resin was analyzed by analytical HPLC to evaluate the glycosylation yields. As shown in Figure 2a, a greater than $90 \%$ glycosylation yield was achieved. Since the glycosylation reaction was performed on solid phase, it was possible to recover valuable unreacted $\mathrm{N}$ glycans easily by filtration ${ }^{20}$, precipitation and silica gel flash chromatography after on-resin coupling, as outlined in Figure 2b. In comparison to in-solution glycosylation reactions used to form $\mathrm{N}$-linked glycoconjugates ${ }^{29,30}$, this on-resin glycosylamine coupling approach simplifies the synthesis of glycoconjugates by reducing purification steps and allows the use of excess $\mathrm{N}$-glycans to drive the glycosylation reaction to completion while also permitting the recovery of valuable excess glycans. Moreover, this is a general approach that can be applied to other types of $\mathrm{N}$-linked oligosaccharides and is compatible with the coupling of protected $\mathrm{N}$-linked glycosylamines if desired.

\subsection{On-resin incorporation of functional handles}

Once the N-linked glycosylated asparagine has been built on solid phase support, it forms a versatile platform for the incorporation of functional handles. The Fmoc protecting group at the N-terminus of asparagine can be cleaved by standard treatment with $20 \%$ piperidine in $\mathrm{DMF}$, and then the exposed amino group is available for conjugation to a wide range of useful chemical handles. To demonstrate on-resin N-terminal labeling, an alkene ( $\mathrm{p}$ vinylbenzoic acid), an alkyne (4-pentynoic acid), biotin, and 5-carboxyfluorescein were chosen. These four functional tags can be utilized in the study of N-linked glycosylation in a variety of ways. For example, alkenes such as p-vinylbenzoic acid can be used to introduce $\mathrm{N}$-glycans into glycopolymers. ${ }^{31}$ This can allow a glycan cluster effect ${ }^{32}$ to enhance sugar mediated interactions in a beneficial manner. One example of this is the use of glycoconjugate polymers to filter pathogenic verotoxins. ${ }^{33}$ The production of glycoconjugates containing alkyne groups allows the use of bio-orthogonal click chemistry which has wide application in bioconjugation chemistry. ${ }^{15,34-36}$ The incorporation of a biotin tag can be used for lectin-sugar interaction studies using avidin affinity 
chromatography and/or avidin coated micro-well plates. ${ }^{37,} 38$ Functionalization of N-linked glycans with 5-carboxyfluorescein introduces a fluorescent chromophore ${ }^{9}$ that can be used in many types of fluorescence experiments. On-resin labeling was achieved by using 10 equivalents of each of the previously specified functional labels, 10 equivalents of DEPBT, and 5 equivalents of DIEA. Ninhydrin tests ${ }^{23}$ showed the completion of the labeling on the $\mathrm{N}$-terminus. Subsequent resin cleavage and anhydrous diethyl ether precipitation provided fairly pure products before any chromatography. Further reverse phase and final normal phase HPLC purifications gave the desired products (shown in Figure 3), VBA-Asparagine $\left(\mathrm{Man}_{8} \mathrm{GlcNAc}_{2}\right)-\mathrm{CONH}_{2}$ 2, Biotin-Asparagine $\left(\mathrm{Man}_{8} \mathrm{GlcNAc}_{2}\right)-\mathrm{CONH}_{2}$ 3, PA-Asparagine $\left(\mathrm{Man}_{8} \mathrm{GlcNAc}_{2}\right)-\mathrm{CONH}_{2}$ 4, 5-FAM-Asparagine $\left(\mathrm{Man}_{8} \mathrm{GlcNAc}_{2}\right)-\mathrm{CONH}_{2} 5$ with good overall yields ranging from $65 \%$ to $85 \%$ according to initial aspartic acid loading determined by Fmoc removal quantification. ${ }^{21}$

\subsection{Utilization of a labeled glycosylated asparagine in a fluorescence polarization assay}

To demonstrate an application of one of the functionalized high mannose glycosylated asparagines synthesized in this study, we utilized 5-FAM-Asparagine ( $\mathrm{Man}_{8} \mathrm{GlcNAc}_{2}$ )$\mathrm{CONH}_{2} 5$ to study the interactions of the high mannose oligosaccharide $\mathrm{Man}_{8} \mathrm{GlcNAc}_{2}$ with the lectin Concanavalin A (ConA $)^{39}$ using fluorescence polarization. In the fluorescence polarization experiment, 5-FAM-Asparagine ( $\left.\mathrm{Man}_{8} \mathrm{GlcNAc}_{2}\right)-\mathrm{CONH}_{2} \mathbf{5}$ was maintained at $20 \mathrm{nM}$ concentration and was titrated with different amounts of ConA. Fluorescence anisotropy values were measured for each concentration of ConA as shown in Figure 4a. The dissociation constant $\left(\mathrm{K}_{\mathrm{d}}\right)$ for ConA binding to $\mathbf{5}$ was estimated by using a one-site binding model to give a $\mathrm{K}_{\mathrm{d}}$ of $444 \mathrm{nM}$. Then, free high mannose $\mathrm{Man}_{8} \mathrm{GlcNAc}_{2}$ was added in to the final solution of the binding experiment (Figure 4a) to inhibit the binding between 5-FAM-Asparagine ( $\mathrm{Man}_{8} \mathrm{GlcNAc}_{2}$ )- $\mathrm{CONH}_{2} \mathbf{5}$ and ConA. The decreasing signal with increasing $\mathrm{Man}_{8} \mathrm{GlcNAc}_{2}$ concentration indicated the initial binding to 5 was based on carbohydrate-lectin interactions rather than ConA interactions with 5-FAM. Moreover, the $\mathrm{K}_{\mathrm{d}}$ value of this experiment gave similar results to isothermal titration calorimetry (ITC) experiments conducted in our laboratory using free high mannose $\mathrm{Man}_{8} \mathrm{GlcNAc}_{2}$ and ConA. ITC yields a similar $\mathrm{K}_{\mathrm{d}}$ of $502 \mathrm{nM}$, indicating the functionalized 5-FAM-Asparagine $\left(\mathrm{Man}_{8} \mathrm{GlcNAc}_{2}\right)-\mathrm{CONH}_{2} \mathbf{5}$ behaves similarly to the free high mannose glycan in this type of fluorescence polarization binding experiment.

\subsection{Summary}

In summary, a versatile and efficient strategy has been developed for the solid phase synthesis of N-linked high mannose glycosylated asparagine allowing incorporation of useful functional handles at the $\mathrm{N}$-terminus. The on-resin glycosylamine coupling was performed successfully using a high mannose oligosaccharide glycosylamine $\mathrm{Man}_{8} \mathrm{GlcNAc}_{2} \mathrm{NH}_{2}$ 1. Excellent glycosylation yields were obtained by using an excess of glycosylamine $\mathbf{1}$, and the use of solid phase synthesis allows the easy recovery of valuable unreacted $\mathrm{N}$-glycans. This approach also provides a synthetic platform for the on-resin $\mathrm{N}$ terminal labeling of glycoconjugates. Different functional handles that can be used in glycobiology studies were incorporated successfully at the $\mathrm{N}$-terminus of high mannose glycosylated asparagine including an alkene, an alkyne, biotin, and 5-carboxyfluorescein. In this synthetic approach the structural integrity of the reducing end monosaccharide is retained, the $\mathrm{N}$-linked glycan is presented with a natural $\mathrm{N}$-glycosidic linkage and the asparagine side chain acts as a linker for the functional handle. The use of solid phase synthesis simplifies the synthesis and purification of these functionalized glycoconjugates which can be difficult to purify due to their hydrophilic nature. If desired it would be straightforward to utilize this on-resin strategy to incorporate longer linkers and/or additional functional groups into glycoconjugates. In addition, the 5-carboxyfluorescein labeled high mannose glycosylated asparagine synthesized in this work has been utilized 
successfully to study the interactions of the lectin Concanavalin A with the high mannose carbohydrate, $\mathrm{Man}_{8} \mathrm{GlcNAc}_{2}$, using a fluorescence polarization assay.

\section{Supplementary Material}

Refer to Web version on PubMed Central for supplementary material.

\section{Acknowledgments}

This project was supported by Indiana University, The University of Kansas, and NIH NIGMS grant R01GM090080. We thank Prof. Richard DiMarchi for solid phase synthesis guidance and use of peptide synthesis facilities. We thank Wenjun Liu and Prof. Dongwhan Lee for assistance with the fluorescence polarization assay. We thank Todd Stone for assistance with ITC. We thank Jonathan A. Karty and Angela M. Hansen for assistance with mass spectrometry.

\section{References}

1. Molinari M. Nat Chem Biol. 2007; 3:313-320. [PubMed: 17510649]

2. Horst AK, Wagener C. Top Curr Chem. 2009; 288:139-156. [PubMed: 22328029]

3. Dove A. Nat Biotechnol. 2001; 19:913-917. [PubMed: 11581651]

4. Koeller KM, Wong CH. Nat Biotechnol. 2000; 18:835-841. [PubMed: 10932151]

5. Seeberger PH, Werz DB. Nature. 2007; 446:1046-1051. [PubMed: 17460666]

6. Warren DJ, Geng X, Danishefsky SJ. Top Curr Chem. 2007; 267:109-141.

7. Galonic DP, Gin DY. Nature. 2007; 446:1000-1007. [PubMed: 17460660]

8. Horlacher T, Seeberger PH. Chem Soc Rev. 2008; 37:1414-1422. [PubMed: 18568167]

9. Esteves AP, Rodrigues LM, Silva ME, Gupta S, Oliveira-Campos AMF, Machalicky O, Mendonca AJ. Tetrahedron. 2005; 61:8625-8632.

10. Munoz FJ, Rumbero A, Sinisterra JV, Santos JI, Andre S, Gabius HJ, Jimenez-Barbero J, Hernaiz MJ. Glycoconjugate J. 2008; 25:633-646.

11. Larsen K, Thygesen MB, Guillaumie F, Willats WG, Jensen KJ. Carbohydr Res. 2006; 341:1209_ 1234. [PubMed: 16716275]

12. Huang CY, Thayer DA, Chang AY, Best MD, Hoffmann J, Head S, Wong CH. PNAS. 2006; 103:15-20. [PubMed: 16373501]

13. Mahal LK, Yarema KJ, Bertozzi CR. Science. 1997; 276:1125-1128. [PubMed: 9173543]

14. Mizuno M, Noguchi M, Imai M, Motoyoshi T, Inazu T. Bioorg Med Chem Lett. 2004; 14:485490. [PubMed: 14698187]

15. Hsu TL, Hanson SR, Kishikawa K, Wang SK, Sawa M, Wong CH. PNAS. 2007; 104:2614-2619. [PubMed: 17296930]

16. Hatch DM, Weiss AA, Kale RR, Iyer SS. ChemBioChem. 2008; 9:2433-2442. [PubMed: 18803208]

17. Zhuang Z, Starkey JA, Mechref Y, Novotny MV, Jacobson SC. Anal Chem. 2007; 79:7170-7175. [PubMed: 17685584]

18. Fukui S, Feizi T, Galustian C, Lawson AM, Chai W. Nat Biotechnol. 2002; 20:1011-1017. [PubMed: 12219077]

19. Oda Y, Nakayama K, Abdul-Rahman B, Kinoshita M, Hashimoto O, Kawasaki N, Hayakawa T, Kakehi K, Tomiya N, Lee YC. J Biol Chem. 2000; 275:26772-26779. [PubMed: 10837483]

20. Chen R, Tolbert TJ. J Am Chem Soc. 2010; 132:3211-3216. [PubMed: 20158247]

21. Kay C, Lorthioir OE, Parr NJ, Congreve M, McKeown SC, Scicinski JJ, Ley SV. Biotechnol Bioeng. 2000; 71:110-118. [PubMed: 11288066]

22. Likhosherstov LM, Novikova OS, Derevitskaja VA, Kochetkov NK. Carbohydr Res. 1986; 146:C1-C5.

23. Kaiser E, Colescot RL, Bossinger CD, Cook PI. Anal Biochem. 1970; 34:595-598. [PubMed: 5443684] 
24. Pace CN, Vajdos F, Fee L, Grimsley G, Gray T. Protein Sci. 1995; 4:2411-2423. [PubMed: 8563639]

25. Cho J, Rando RR. Nucleic Acids Res. 2000; 28:2158-2163. [PubMed: 10773086]

26. Lal A, Pang P, Kalelkar S, Romero PA, Herscovics A, Moremen KW. Glycobiology. 1998; 8:981995. [PubMed: 9719679]

27. Garcia-Martin F, Quintanar-Audelo M, Garcia-Ramos Y, Cruz LJ, Gravel C, Furic R, Cote S, Tulla-Puche J, Albericio F. J Comb Chem. 2006; 8:213-220. [PubMed: 16529516]

28. Yue CW, Thierry J, Potier P. Tetrahedron Lett. 1993; 34:323-326.

29. Kumar V, Ramesh NG. Org Biomol Chem. 2007; 5:3847-3858. [PubMed: 18004466]

30. Meinjohanns E, Meldal M, Paulsen H, Dwek RA, Bock K. J Chem Soc, Perkin Trans 1. 1998:549_ 560.

31. Kobayashi K, Tsuchida A, Usui T, Akaike T. Macromolecules. 1997; 30:2016-2020.

32. Scanlan CN, Offer J, Zitzmann N, Dwek RA. Nature. 2007; 446:1038-1045. [PubMed: 17460665]

33. Miyagawa A, Kasuya MCZ, Hatanaka K. Chem Lett. 2008; 37:438-439.

34. Huisgen R. Pure Appl Chem. 1989; 61:613-628.

35. Lee DJ, Mandal K, Harris PWR, Brimble MA, Kent SBH. Org Lett. 2009; 11:5270-5273. [PubMed: 19842689]

36. Tornoe CW, Christensen C, Meldal M. J Org Chem. 2002; 67:3057-3064. [PubMed: 11975567]

37. Diaco R, Hill JH, Hill EK, Tachibana H, Durand DP. J Gen Virol. 1985; 66:2089-2094.

38. Hofmann K, Finn FM, Kiso Y. J Am Chem Soc. 1978; 100:3585-3590.

39. Mandal DK, Kishore N, Brewer CF. Biochemistry. 1994; 33:1149-1156. [PubMed: 8110746] 


\section{Highlights}

- Efficient solid phase synthesis of high mannose glycosylated Asparagine

- Versatile on-resin conjugation of functional groups to glycosylated asparagine

- Simplified purification of labeled glycans and recovery of unreacted material

- Functionalized glycans used in a fluorescence polarization binding experiment 
a)<smiles>CC(F)(OC(=O)CC(NC=O)C(=O)O)c1ccccc1</smiles><smiles>NC(CC(=O)NCC(=O)OCC(=O)O)C(=O)O</smiles>

Figure 1. b)
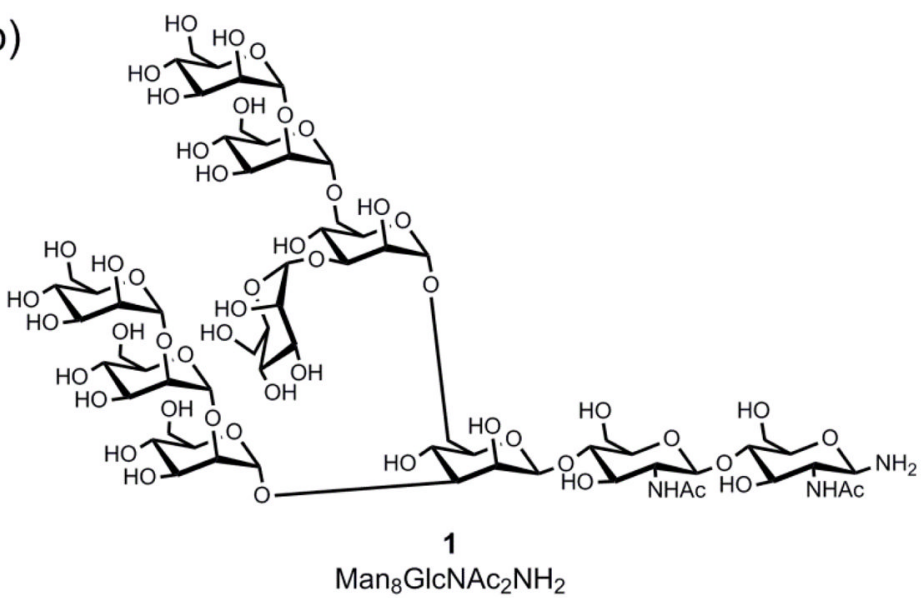

c)

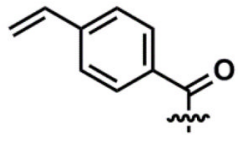

VBA-Asn( $\left.\operatorname{Man}_{8} \mathrm{GlcNAc}_{2}\right)-\mathrm{CONH}_{2} \quad$ Biotin-Asn( $\left.\mathrm{Man}_{8} \mathrm{GlcNAc}_{2}\right)-\mathrm{CONH}_{2}$<smiles>C#CCCC(=O)C(C)(C)C</smiles>

4

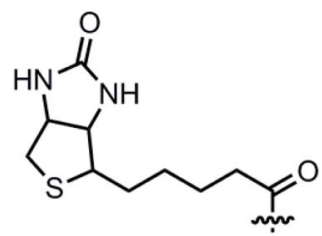

3

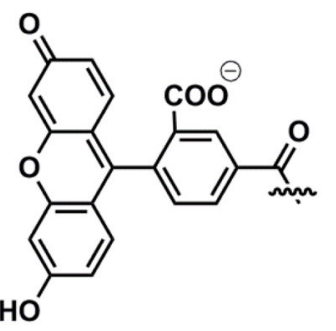

5
PA-Asn $\left(\mathrm{Man}_{8} \mathrm{GlcNAc}_{2}\right)-\mathrm{CONH}_{2}$

(a) Synthetic strategy: i. 1\% TFA in DCM; ii. 3 equiv. of glycosylamine 1, 3 equiv. of DEPBT, and 1.5 equiv. of DIEA, 12 hours; iii. $20 \%$ piperidine in DMF; iv. 10 equiv. of each of the functionalization group carboxylic acids (X); 10 equiv. of DEPBT, and 5 equiv. of DIEA, 6 hours, v. neat TFA with $1 \%$ TIS scavenger, (b) high mannose $\mathrm{Man}_{8} \mathrm{GlcNAc}_{2}$ glycosylamine, (c) functional handles incorporated into glycoconjugates. 

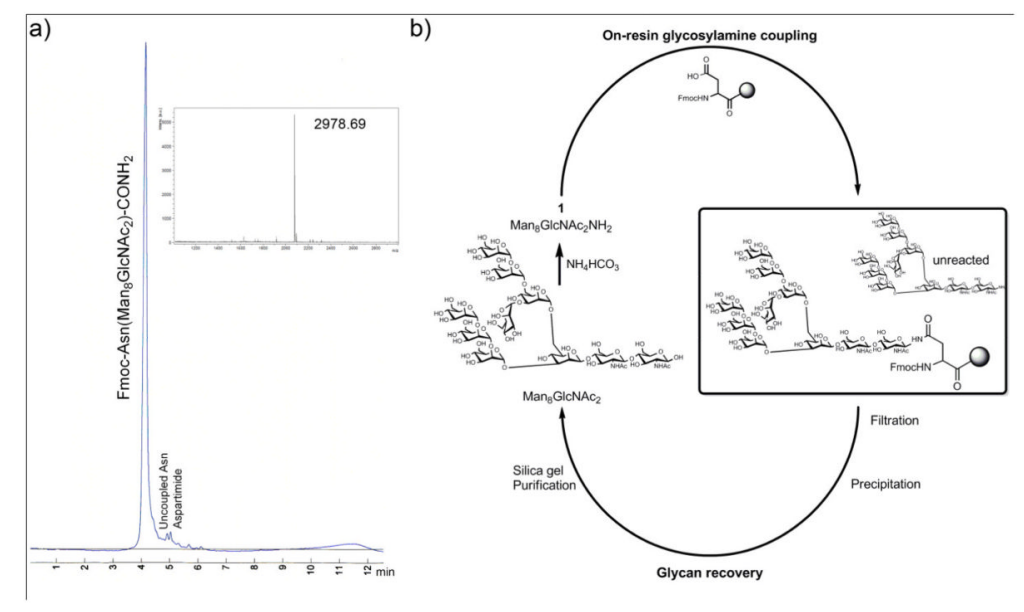

Figure 2.

On-resin glycosylamine coupling and glycan recovery. (a) Analytical HPLC and MALDITOF-MS for a crude sample from on-resin coupling of glycosylamine 1, expected mass for Fmoc-Asp $\left(\mathrm{Man}_{8} \mathrm{GlcNAc}_{2}\right)-\mathrm{CONH}_{2},[\mathrm{M}+\mathrm{Na}]^{+}=2078.71$. (b) Scheme for recovery and reuse of the unreacted, excess high mannose oligosaccharide $\mathrm{Man}_{8} \mathrm{GlcNAc}_{2}$. 

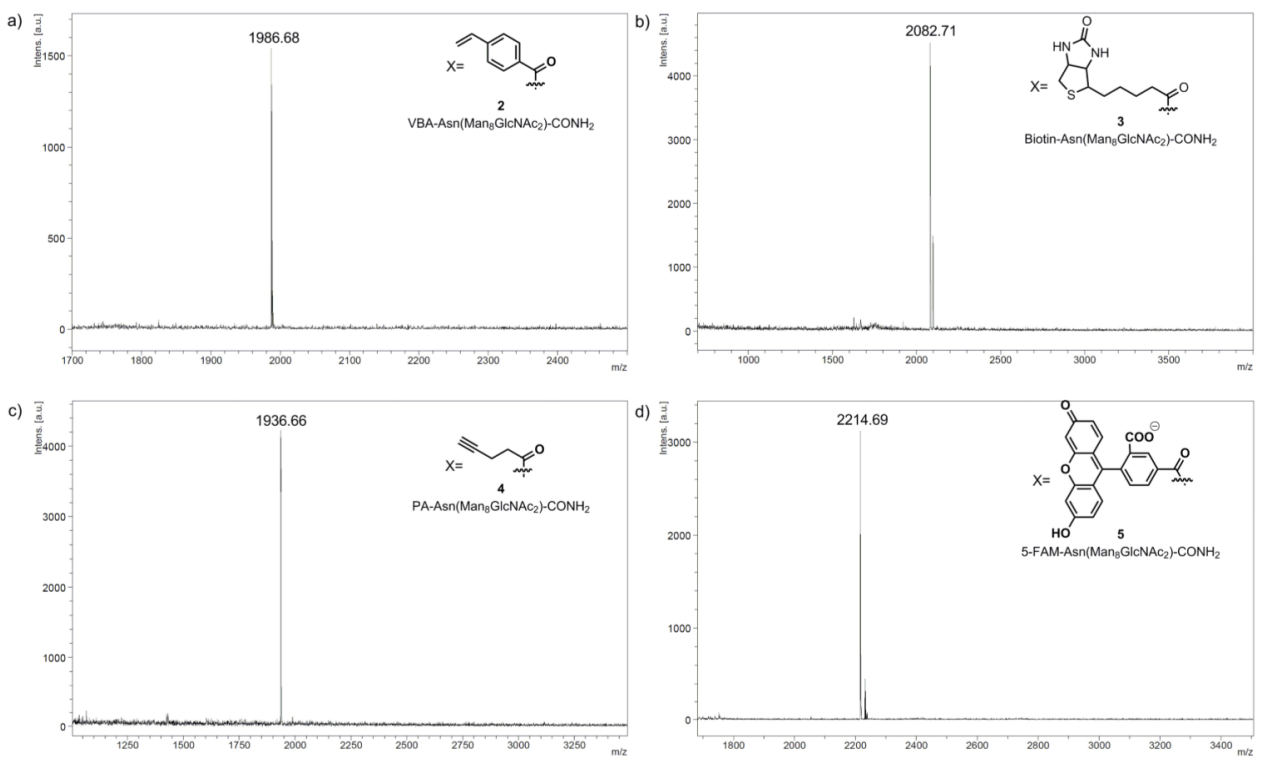

Figure 3.

MALDI-TOF-MS for functionalized high mannose asparagines. a) VBA-Asparagine $\left(\mathrm{Man}_{8} \mathrm{GlcNAc}_{2}\right)-\mathrm{CONH}_{2} 2$, expected mass: $\left.[\mathrm{M}+\mathrm{Na}]^{+}=1986.68, \mathrm{~b}\right)$ Biotin-Asn $\left(\mathrm{Man}_{8} \mathrm{GlcNAc}_{2}\right)-\mathrm{CONH}_{2} \mathbf{3}$, expected mass: $\left.[\mathrm{M}+\mathrm{Na}]^{+}=2082.72, \mathrm{c}\right)$ PA-Asn $\left(\mathrm{Man}_{8} \mathrm{GlcNAc}_{2}\right)-\mathrm{CONH}_{2} 4$, expected mass: $[\mathrm{M}+\mathrm{Na}]^{+}=1936.67$, d) 5-FAMAsn $\left(\mathrm{Man}_{8} \mathrm{GlcNAc}_{2}\right)-\mathrm{CONH}_{2} \mathbf{5}$, expected mass: $[\mathrm{M}+\mathrm{Na}]^{+}=2214.69$. 


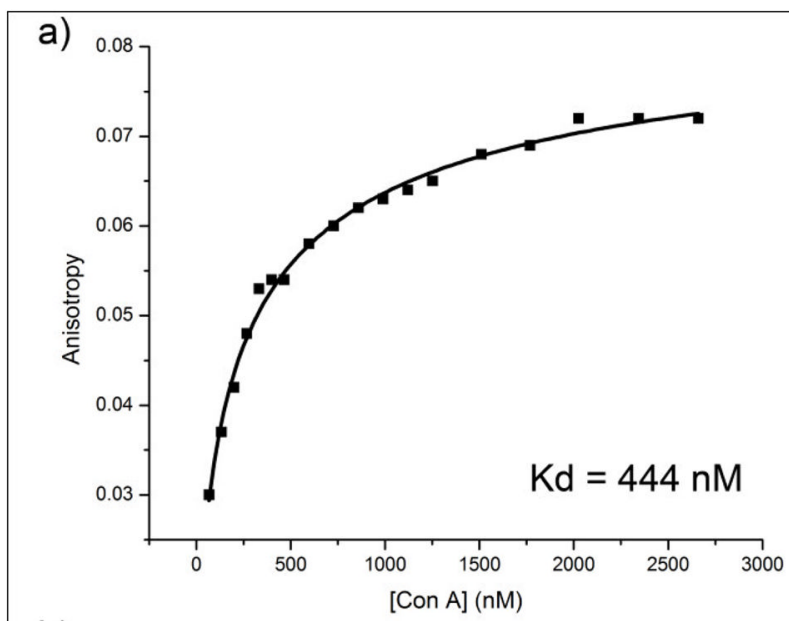

c)

b)
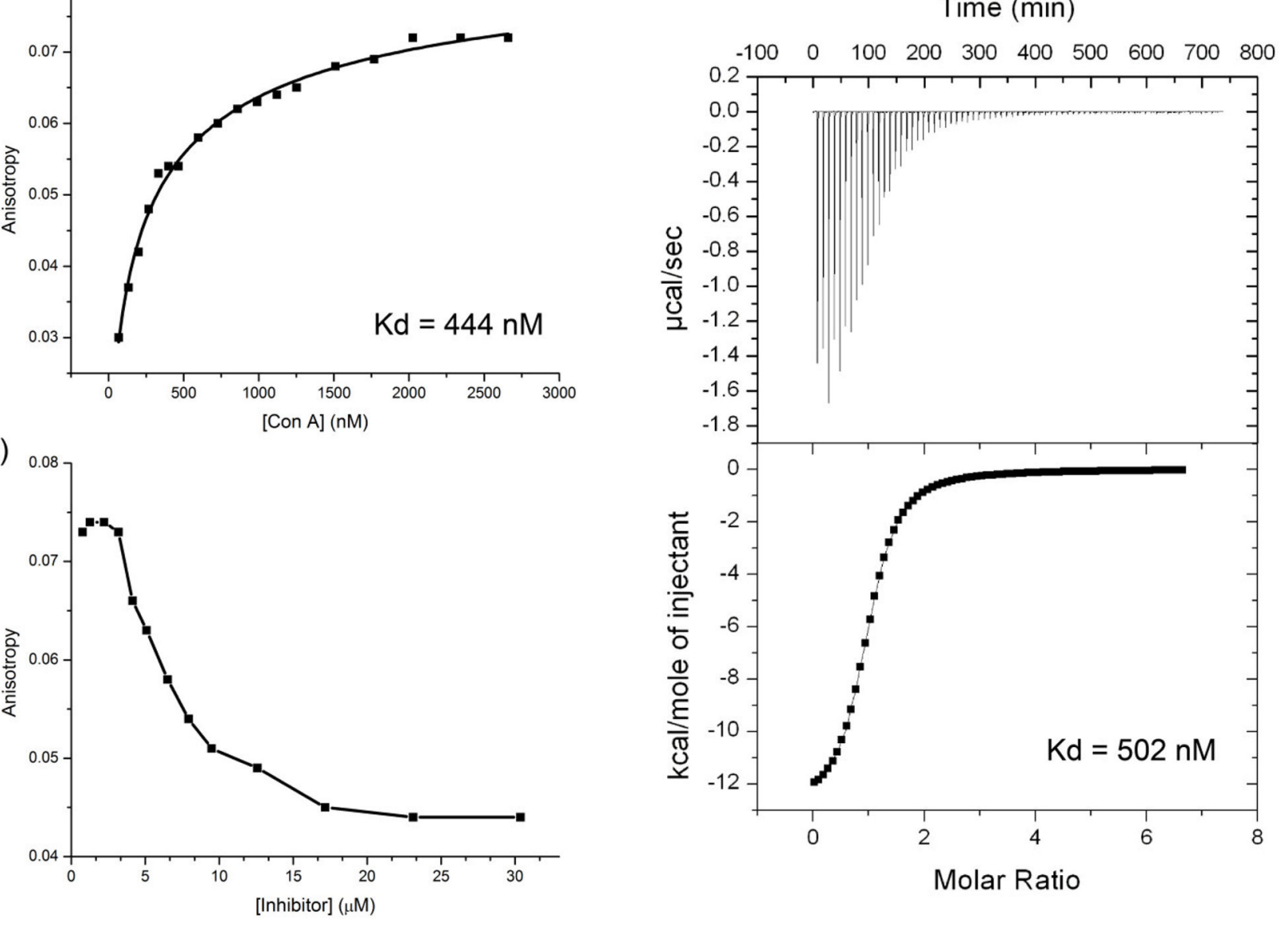

Figure 4.

a) Fluorescence polarization assay of 5-FAM-Asparagine $\left(\mathrm{Man}_{8} \mathrm{GlcNAc}_{2}\right)-\mathrm{CONH}_{2} \mathbf{5}$ binding with ConA. The concentration of 5-FAM-Asparagine ( $\left.\mathrm{Man}_{8} \mathrm{GlcNAc}_{2}\right)-\mathrm{CONH}_{2} \mathbf{5}$ was $20 \mathrm{nM}$, Kd (dissociation constant) was determined using a one-site model analysis to give a Kd for ConA of $444 \mathrm{nM}$, b) fluorescence polarization assay of ConA binding inhibition, $\mathrm{Man}_{8} \mathrm{GlcNAc}_{2}$ was used as the inhibitor, which was titrated directly into the final solution from the binding assay shown in a), c) isothermal titration calorimetry assay of $\mathrm{Man}_{8} \mathrm{GlcNAc}_{2}$ binding with ConA, Kd was determined using sigmoidal curve fitting to give a Kd for ConA of $502 \mathrm{nM}$. 